\title{
DÜBLIN
}

Technological University Dublin

ARROW@TU Dublin

1994-01-01

\section{Cyclic voltammetry of polypyrroledodecylbenzenesulfonate layers}

\author{
T. McCormac \\ Technological University Dublin \\ W. Breen \\ Technological University Dublin \\ A. McGee \\ Technological University Dublin
}

See next page for additional authors

Follow this and additional works at: https://arrow.tudublin.ie/scschcpsart

Part of the Chemistry Commons

\section{Recommended Citation}

McCormac, T., Breen, W., McGee, A., Cassidy, J.F., Lyons, M.E.G.:Cyclic voltammetry of

polypyrroledodecylbenzenesulfonate layers. Electroanalysis, Vol. 7, 1995, pp.287-289. doi:10.1002/

elan.1140070317

This Article is brought to you for free and open access by the School of Chemical and Pharmaceutical Sciences at ARROW@TU Dublin. It has been accepted for inclusion in Articles by an authorized administrator of ARROW@TU Dublin. For more information, please contact arrow.admin@tudublin.ie, aisling.coyne@tudublin.ie, gerard.connolly@tudublin.ie.

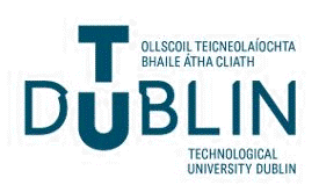




\section{Authors}

T. McCormac, W. Breen, A. McGee, John Cassidy, and M. E.G. Lyons 


\title{
Cyclic Voltammetry of Polypyrroledodecylbenzenesulfonate Layers
}

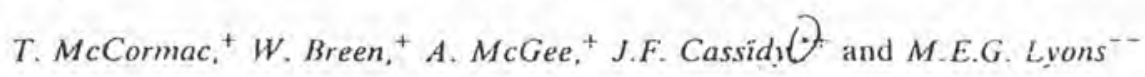

Chemistry Department, Dublin Institute of Technology, Kevin Strect, Dublin 8, 1reland

* Chemistry Department, Trinity College, Dublin 2, Ireland

Received: January 14, 1994

Final version: April 8, 1994

\begin{abstract}
Absiract
Polypyrrole was deposited from solutions of $\mathrm{NaClO}_{4}$ and $\mathrm{NaDBS}$, where DBS is dodecylbenzenesulfonate, in aqueous solution and characterized by voltammetry. It is found that the absence of the so-called 'double laver charging current' during cyclic voltammetry of the layers formed from solutions with surfactant is not because of the order in morphelogy of the layer, but irreversible incorporation of the surfactant anion.
\end{abstract}

Keywords: Polypyrrole, Dodecylbenzencsulfonate, Cyclic voltammetry, Modified electrode.

The electrochemical behavior of conducting polymers has more recently been envisaged in terms of electron transfer between sites within and between chains rather than the metallic-like behavior formerly proposed [1-3]. Transmission line models composed of a resistance due to electron transport along and between chains in parallel with a resistance associated with ionic transport have become popular [4-6]. In general, the resistance due to movement of ions through pores is less than the resistance due to redox conduction of electrons through the layer [3]. The role of morphology of the layer and the nature of charge carrying ions is important in defining the relative values of these two resistance values. Recently the use of larger anions as dopants has been studied [7-10]. Of these, dodecylbenzenesulfonate (DBS) has been shown to exhibit unusual electrochemistry [11] and this article describes some further work on the polypyrroledodecylbenzenesulfonate (PPDBS) layer.

See the Experimental section for details of the procedure followed. It was found [12] that PPDBS layers, when examined under SEM were flat and showed no features, unlike polypyrrole perchlorate, $\mathrm{PPClO}_{4}$, which displayed a cauliflower-like morphology.

Figure 1 shows the cyclic voltammetry of a layer, previously formed in an aqueous $0.1 \mathrm{~mol} \mathrm{dm}^{-3} \mathrm{LiClO}_{4} / 0.1 \mathrm{~mol} \mathrm{dm}^{-3}$ pyrrole solution, washed in deionized water and transferred to a solution of $0.1 \mathrm{~mol} \mathrm{dm}^{-3} \mathrm{LiClO}_{4}$. The characteristic 'doublelayer charging-like' behavior can be seen clearly and the current magnitude at the switching potential has previously been used to determine the capacitance of the layer [13]. The broad nature of the voltammetry indicates that the system does not merely consist of a simple surface-confined redox species. Models for this behavior include that of a series of oligomers, each of which has a characteristic formal potential leading to a broad voltammetry [14]. It has also been proposed that the broad voltammetry has been due to electrostatic repulsions between oxidized sites in the polymer $[15,16]$. Such a capacitive-like behavior has been seen for polypyrrole, previously formed in solutions of pyrrole and tetrabutylammonium perchlorate, and run in electrolytes such as $\mathrm{NaCl}, \mathrm{NaNO}_{3}$, and has been absent in solutions of $\mathrm{Na}_{2} \mathrm{CO}_{3}$ and $\mathrm{Na}_{2} \mathrm{SO}_{4}$ [17].

Figure 2 shows a layer formed in $0.1 \mathrm{~mol} \mathrm{dm}^{-3} \mathrm{NaDBS} /$ $0.1 \mathrm{~mol} \mathrm{dm}^{-3}$ pyrrole and cycled in $0.1 \mathrm{~mol} \mathrm{dm}^{-3} \mathrm{NaClO}_{4}$. The voltammograms in Figures 1 and 2 represent the final steady state voltammetry of the layer in the particular electrolyte. It may take 20-30 scans to reach a situation where a steady state voltammetry is seen. Previously it has been reported that continued cycling causes a greater than equilibrium concentration of electrolyte in the pores for the film [18], which may account for the 'breaking-in' process. The small degree of double layer charging, seen at the switching potential in Figure 2 , has been attributed to the ordering of the layer during its formation in the surfactant solution $[8,9,11]$. It can be seen that the predominant ionic movement is that of cations since the peak shifts in a positive direction with increasing electrolyte concentration; this is in common with previous experimental results $[19,20]$. If the potential is scanned over a potential region

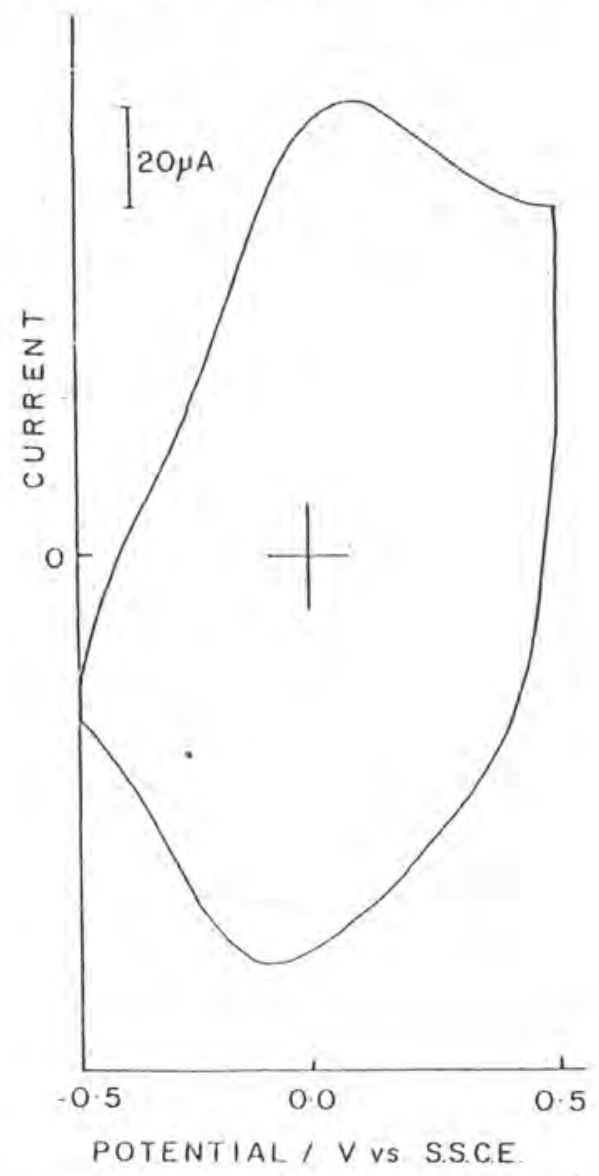

Fig. 1. Cyclic voltammetry of a layer formed in $0.1 \mathrm{~mol} \mathrm{dm}^{-3} \mathrm{LiClO}_{4}$ $0.1 \mathrm{~mol} \mathrm{dm}^{-3}$ pyrrole by scanning continuously between 0.0 and $0.8 \mathrm{~V}$ until $20 \mathrm{mC}$ of charge had passed. The layer was then translerred to $0.1 \mathrm{~mol} \mathrm{dm}^{-3} \mathrm{LiClO}_{4}$. Scan rate: $50 \mathrm{mV} / \mathrm{s}$. Pt electrode area: $0.0707 \mathrm{~cm}^{2}$ 


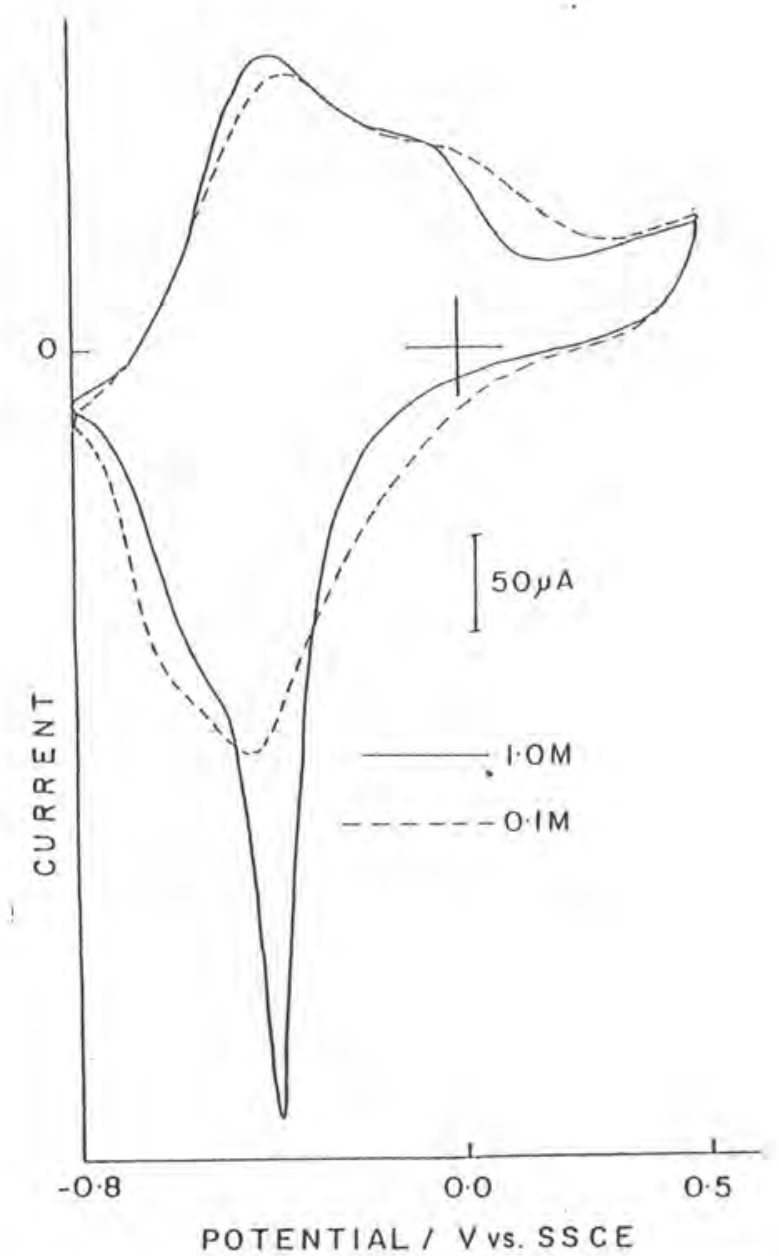

Fig. 2. Cyclic voltammetry of a layer formed in $0.1 \mathrm{~mol} \mathrm{dm}^{-3} \mathrm{NaDBS} /$ $0.1 \mathrm{~mol} \mathrm{dm}^{-3}$ pyrrole by scanning continuously between 0 and $0.78 \mathrm{~V}$ until $20 \mathrm{mC}$ of charge had passed. The layer was then transferred to $\mathrm{NaClO}_{4}$ solutions where the concentrations are shown in the figure. Scan rate: $50 \mathrm{mV} / \mathrm{s}$, Pt electrode area: $0.0707 \mathrm{~cm}^{2}$.

more positive than $-0.2 \mathrm{~V}$, there is very little capacitive-like current which has been reported to be due to the morphology of the layer $[11,19]$.

Many cyclic voltammetric studies of polypyrrole, formed from a solution of a large anion, are carried out in solutions of either the same anion or smaller anions as electrolyte. In these cases the cation in solution moves in and out during the redox reactions of the layer. In this work a polypyrrole perchlorate layer is cycled in a solution containing sodium dodecylbenzenesulfonate and it was found that the dodecylbenzenesulfonate exchanged into the layer. Figure 3 shows the voltammetry of a layer formed in $0.1 \mathrm{~mol} \mathrm{drin}^{-3} \mathrm{NaClO}_{4} / 0.1 \mathrm{~mol} \mathrm{dm}^{-3}$ pyrrole and run in NaDBS. It can be seen that there is a definite change in the electrochemical characteristics of the film when a layer is formed in $\mathrm{NaClO}_{4}$ and transferred to a surfactant solution. There appears a sharp peak at $-0.7 \mathrm{~V}$, similar to, but more negative than that in Figure 2. It can be seen from Figure 3, that despite the size of DBS, it can replace some $\mathrm{ClO}_{4}^{-}$in the layer. Once.DBS has entered into the layer, it is cation movement that defines the ionic mobility as can be seen when the background clectrolytc concentration is increased, the peak moves in a positive direction. The DBS irreversibly enters into the layer, since when this electrode was subsequently placed in $0.1 \mathrm{~mol} \mathrm{dm}^{-3} \mathrm{NaClO}_{4}$, the DBS did not fully exchange out on cycling. Since the morphology of the layer is determined by the

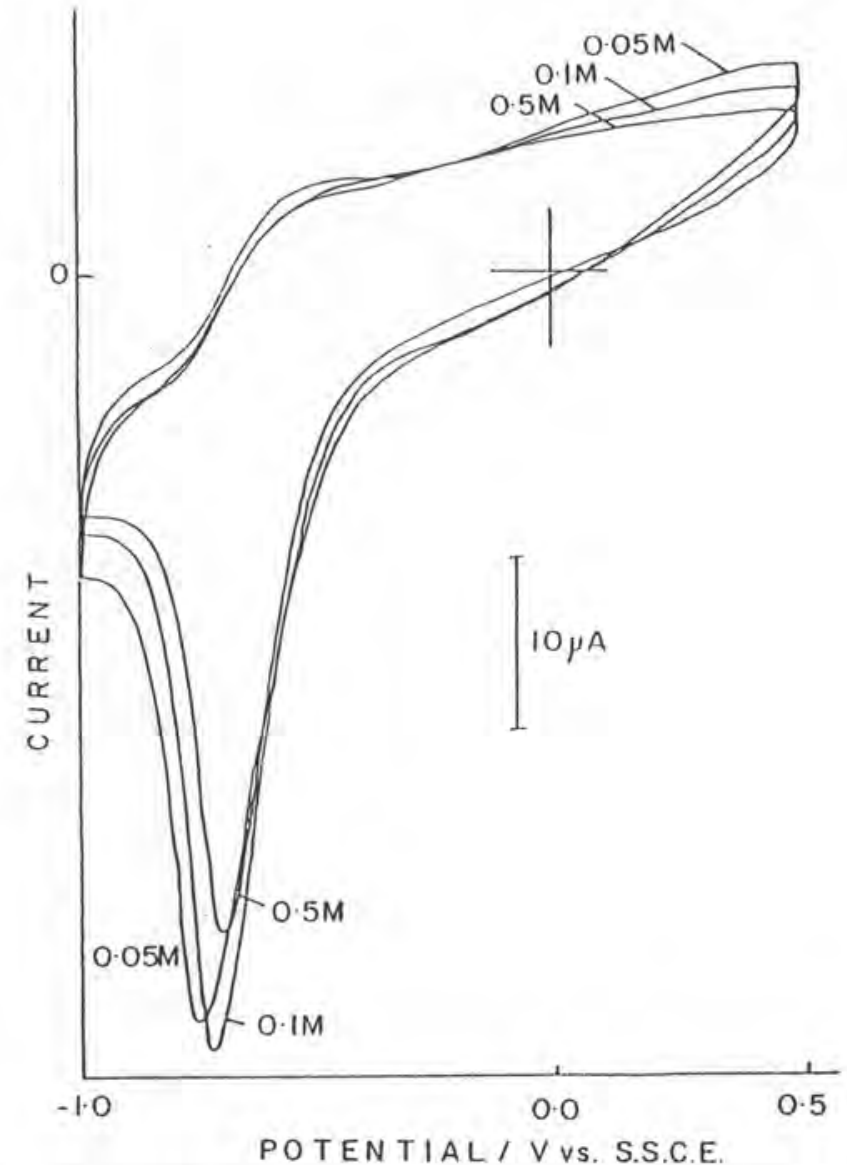

Fig. 3. Cyclic voltammetry of a layer formed in $0.1 \mathrm{~mol} \mathrm{dm}^{-3} \mathrm{NaClO}_{4} /$ $0.1 \mathrm{~mol} \mathrm{dm}^{-3}$ pyrrole by scanning continuously between 0 and $0.8 \mathrm{~V}$ until $20 \mathrm{mC}$ of charge had passed. The layer was then transferred to NaDBS solutions; the concentrations are shown in the figure. Scan rate: $50 \mathrm{mV} / \mathrm{s}$, Pt electrode area: $0.0707 \mathrm{~cm}^{2}$.

conditions of its formation, the double layer charging characteristics of Figure 1 is a function of the electrolyte since it has been suppressed in DBS solution. It can be seen, however, that the current magnitude is much less in Figure 3 than in the first two figures indicating that there is only a partial exchange of $\mathrm{ClO}_{4}^{-}$with DBS. It has been shown elsewhere [21], by probe beam deflection, that $\mathrm{Cl}^{-}$can partially replace dodecylsulfate from a polypyrrole dodecylsulfate layer implying that the movement of large anions out of polypyrrole layers is possible. This is in contrast with previous reports of only cation movement for polypyrrole dodecylsulfate $[20,22,23]$ and polypyrrole dodecylbenzenesulfonate [24]. Figure 4 shows a layer formed in a solution of $0.1 \mathrm{moldm}^{-3} \mathrm{NaDBS}$ and $0.1 \mathrm{~mol} \mathrm{dm}^{-3}$ pyrrole and transferred to a solution of $0.1 \mathrm{~mol} \mathrm{dm}^{-3} \mathrm{LiClO}_{4}$. In the $\mathrm{ClO}_{4}^{-}$solution it can be seen that a peak at negative potentials is characteristic of the movement of cations. However, it can be also seen that there is a peak due to the movement of $\mathrm{ClO}_{4}^{-}$close to $0.0 \mathrm{~V}$ which is not as dominant in $\mathrm{NaClO}_{4}$ (see Figure 2). This may be because of the greater hydrated radius of $\mathrm{Li}^{+}$which makes its incorporation more difficult. For polypyrrole layers formed with $\left[\mathrm{Fe}(\mathrm{CN})_{6}\right]^{4-}$ as anions [25], $\mathrm{Li}^{+}$was the most difficult cation of the alkalies to be incorporated, which is also the case for polypyrrole formed in the presence of cupric hexacyanoferrate [26].

It should be noted that the concentration of the surfactant $(0.1 \mathrm{M})$, is above the critical micelle concentration $\left(1.2 \times 10^{-3} \mathrm{~mol} \mathrm{dm}^{-3},[27]\right)$. It was found that a layer formed in a $1 \times 10^{-3} \mathrm{~mol} \mathrm{dm}^{-3} \mathrm{NaDBS} / 0.1 \mathrm{~mol} \mathrm{dm}^{-3}$ pyrrole, which 


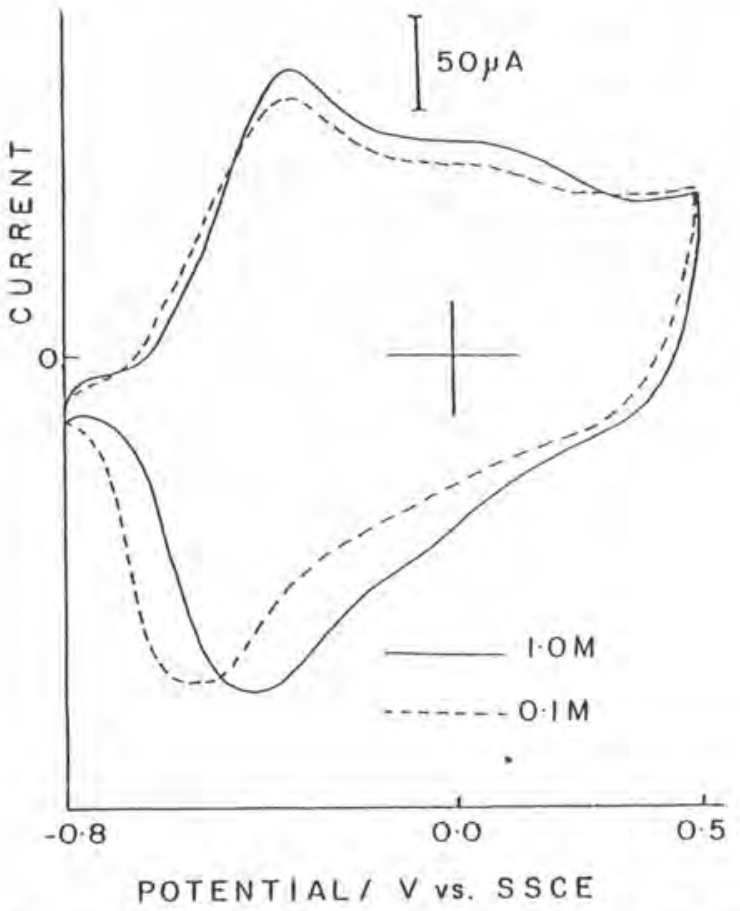

Fig. 4. Cyclic voltammetry of a layer formed in $0.1 \mathrm{~mol} \mathrm{dm}^{-3} \mathrm{NaDBS} /$ $0.1 \mathrm{~mol} \mathrm{dm}^{-3}$ pyrrole by scanning continuously between 0 and $0.8 \mathrm{~V}$ until $20 \mathrm{mC}$ charge had passed. The layer was then transferred to $\mathrm{LiClO}_{4}$ solutions; the concentrations are shown in the figure. Scan rate: $50 \mathrm{mV} / \mathrm{s}$, Pt electrode area: $0.0707 \mathrm{~cm}^{2}$.

takes a greater number of scans to form, exhibits identical behavior to that in Figure 4 showing that the layer morphology is not affected by the DBS concentration in the solution in which the PP is formed.

It can be seen that DBS irreversibly enters into PP layers and that electrochemistry is dominated by cation movement. So much so that when a $\mathrm{PPClO}_{4}$ layer is placed in a DBS solution, the DBS extracts itself into the layer and the electrochemistry on cycling is dominated by cation movement. That the layer electrochemistry is not due to the morphology of the layer can be seen since when a layer formed in $\mathrm{ClO}_{4}^{-}$(cauliflower-like morphology, viewed by SEM [12]) is placed in DBS, its electrochemistry is similar to that formed in DBS (which has a flatter morphology viewed by SEM). Therefore the electrochemistry and notably the small 'double layer charging current' is due to the presence of a large anion in solution rather than the polymer morphology as has previously been implied.

\section{Experimental}

Sodium dodecylbenzenesulfonate (NaDBS, Aldrich) was technical grade. Pyrrole (Aldrich) was distilled and stored in the dark under nitrogen before use. Water was distilled and deionized. A conventional single compartment three electrode cell was employed for electrochemistry. The potentiostat consisted of a Sycopel Model DP301, which was linked to a JJLloyd PL3 chart recorder. All potentials are yuoted with respect to a calomel electrode in saturated aqueous $\mathrm{NaCl}$. All electrochemistry was carried out at a platinum disk (geometric area: $0.071 \mathrm{~cm}^{2}$ ) which was polished with $0.3 \mu \mathrm{m}$ alumina (Leco) on felt prior to use. A carbon rod served as the auxiliary electrode.

Polymer preparation. Polymer layers were formed in aqueous solution by scanning the platinum electrode potential between the limits $0.0 \mathrm{~V}$ and $+0.8 \mathrm{~V}$ and monitoring the charge until a total anodic charge of $20 \mathrm{mC}$ passed.

\section{Acknowledgment}

J.C. thanks EOLAS for support from grants $A R P / 61$ and $\mathrm{ST} / 91 / 001 / \mathrm{B}$.

\section{References}

[1] S. Fletcher, J. Electroanal. Chem. 1992, 337, 127.

(2) X. Ren, P.G. Pickup, J. Chem. Soc. Faraday Trans. 1993, 89, 321.

[3] X. Ren, P.G. Pickup, J. Electrochem. Soc. 1992, 139, 2097.

[4] S. Fletcher, J. Chem. Soc. Faraday Trans. 1993, 89, 311

[5] W.J. Albery, C.M. Elliott, A.R. Mount, J. Eleciroanal. Chem. 1990, $28 s$. 15.

16] W.J. Albery, A.R. Mount, J. Electroanal. Chem, 1991, 305, 3.

[7] J.M. Pernaut, R.C.D. Peres, V.F. Juliano, M.A. De Paoli, J. Eleciruanat. Chem., 1989, 2i4, 225.

18] L.F. Warren, D.P. Anderson, J. Electrochem. Soc, 1987, 134, 101.

[9] L.F. Warren, J.A. Walker, D.P. Anderson, C.G. Rhodes, L.J. Buckley. J. Electrochem. Soc. 1989, 136, 2286.

[10] X. Ren, P.G. Pickup, J. Phys. Chem. 1993, 97, 5356.

[11] M.E.G. Lyons, W. Breen, J. Cassidy, J. Chem. Soc, Faraday Trans. 1991. $87,115$.

[12] W. Breen, Ph.D. Thesis, University of Dublin 1991.

[13] S. Panero, P. Prosperi, S. Passerini, B. Scrosati, D.P. Perlmutter, J. Electrochem. Soc. 1989, 136, 3729.

[14] J. Heinze, M. Storzbach, J. Mortensen, Ber. Bunsenges. Physikal. Chemie. 1987, 91, 960.

[15] M.E.G. Lyons, H.G. Fay, T. McCabe, J. Corish, J.G. Vos, A.J. Kelly, J. Chem. Soc. Faraday Trans, 1990, 86, 2905.

[16] M.E.G. Lyoos, H.G. Fay, T. McCabe, Key Eng. Mater. 1992, 72/74, 381

[17] R. John, G.G. Wallace, J. Electroanal. Chem. 1993, 354, 145.

[18] G.L. Duffitt, P.G. Pickup, J. Chem. Soc. Faraday Trans. 1992, 88, 1417.

[19] M.E.G. Lyons, C.H. Lyons, C. Fitzgerald, T. Bannon, Analyst 1993, 118, 361.

[20] C. Zhong, K. Doblhofer, Electrochim. Acta 1990, 35, 1971.

[21] V.M. Schmidt, C. Barbero, R. Kotz, J. Electroanal. Chem. 1993, 352, 301.

[22] C. Zhong, K. Doblhofer, G. Weinberg, J. Chem. Soc., Faraday Discuss. $1989,88,307$.

[23] M.A. dePaoii, S. Panero, P. Prosperi, B. Scrosati, Electrochim. Acta $1990,35,1145$

[24] M.A. dePao'. S.C.D. Peres, S. Panero, B. Scrosati, Electruchim. deta $1992,37,117 \%$

[25] IV. Breen, J.F. Cassidy, M.E.G. Lyons, J. Electroanal Chem. 1991. 29745.

[26] Y. Li, W. Zhang, S. Dong, Electroanalysis 1993, 5, 431

[27] R.J. Hunter. Zeta Potential in Colloid Science, Principles and Applica. tions, Acaderaic Press, London 1981. 